\title{
Stress Modulated Physiological Responses in Nile Tilapia, Oreochromisniloticus, Treated with Non-Ascorbic Acid Supplemented Feed
}

\author{
Ahmed Mustafa ${ }^{*}$, Sharif Abu Hayat, Parveen Quarrar \\ Department of Biology Indiana University Purdue University Fort Wayne \\ 2101 E. Coliseum Blvd., Fort Wayne, IN 46805, USA \\ *Corresponding Author: mustafaa@ipfw.edu
}

Copyright (C) 2013 Horizon Research Publishing All rights reserved.

\begin{abstract}
Stress caused by the aquaculture environment hampers normal growth and immune response of fish and makes them susceptible to diseases. Ascorbic acid (vitamin C), on the other hand, has been known to improve the immune response. Experiments were conducted to investigate the effects of the absence of vitamin $C$ in fish dietgrown in stressed condition induced by crowding. Fish fingerlings were obtained from a local fish farm and were acclimated in the new environment for two weeks. After the acclimation period, fish were maintained in two different conditions: controlled and stressed (density $>50 \mathrm{~g} / \mathrm{l}$ ). Within each condition, fish were further divided into two diet groups, each with two replicates. The experimental groups were fed vitamin $\mathrm{C}$ supplemented $(1000 \mathrm{mg} / \mathrm{kg})$ feed and the control groups were fed vitamin $\mathrm{C}$ free feed for fifteen days. Six fish from each group were sampled to assess the physiological parameters: plasmacortisol, blood glucose, plasma protein, packed cell volume, spleen somatic index, and condition factor. Fish in the stressed conditions showed significantly higher level $(p<0.05)$ of plasma cortisol, blood glucose indicating stress, both of which were reduced when fed vitamin $\mathrm{C}$ supplemented diet. Significantly higher $(p<0.05)$ hematocrit concentration was observed in the vitamin $\mathrm{C}$ fed group indicating better physiological adaptation.
\end{abstract}

Keywords Tilapia, Stress, Immune Response, Ascorbic Acid

\section{Introduction}

In chronic stress situation, hypothalamus of fish releases hypothalamic factors which excite pituitary gland to synthesize adrenocorticotropic hormone (ACTH), melanophore stimulating hormone (MSH), and $\beta$-endorphin $(\beta$-END). These hormones induce inter-renal cells to synthesize cortisol, a steroid hormone with broad spectrum activities enabling the fish adapt to stress[1]. Its primary function is to increase blood sugar through gluconeogenesis and thus increase energy availability. Activities of cortisol also include downregulation of the Interleukin-2 receptor (IL-2R), enhancement of glycogenolysis, and proteolysis(Barton and Iwama, 1991). Cortisol has been linked directly with growth reduction, immunosuppression and declined reproductive capabilities [1].

Ascorbic acid(vitamin C) is an important molecule for normal growth and metabolic functions of fish. It has been widely used as dietary supplement asalmost all fish lack the last enzyme of vitamin C biosynthetic pathway, L-gulonolactone oxidase [2]. Protection of living cells from oxidative damage is provided by ascorbic acid by neutralizing the reactive oxygen species[3]. Collagenization is an important step in development of connective tissue and wound healing. Ascorbic acid is a critical cofactor in formation of collagen molecules through hydroxylation of proline and lysine [4]. Jaunceyet al. [5]demonstrated that lack of ascorbate in fish diet slows wound healing. Ascorbic acid has also been reported to decrease the toxic effects of heavy metals such as nickel, cadmium [6] and mercury [7].

Immune system is boosted by vitamin $\mathrm{C}$ in a number of ways - protectionfrom free-radical mediated protein inactivation in macrophages, chemotaxis, stimulation in production of antibody and interferon, signaling of rapid proliferation of immune cells and complement activation [8, 9]. Ascorbic acid induces regeneration of vitamin E, a fat-soluble antioxidant, which is present in the lipid of cell membranes and lipoproteins to fight free radical-mediated peroxidation [10].

In stressful conditions of aquaculture depletion of ascorbic acid takes place faster than normal situations [11].Stocking density of more than $40 \mathrm{~g} / 1$ is considered to be stressful for most teleost [12]. The response mechanisms against even sub lethal disturbances in chronic situations result a net detrimental effect on the fish health, and is regarded as maladaptive[13]. High dose of vitamin $\mathrm{C}$ supplementation 
has been suggested to mitigate the effects of physiological stress[14]. Kibatchi [15] stated that ascorbate in high concentration inhibit steroid synthesis and therefore might reduce the severity of cortisol mediated stress responses.

The objective of this experiment was to determine the physiological effects of absolute ascorbic acid deficiency in tilapia that are stressed by crowding.

\section{Materials and Methods}

\subsection{Fish Acquisition and Maintenance}

Nile tilapia,Oreochromisniloticus fingerlings (mean weight 30 grams) were purchased from Troyer's Farm, IN and transported to the Life Sciences Resource Center at Indiana University-Purdue University, Fort Wayne. The fish were acclimated in 500 liter tanks containing recirculating dechlorinated water for two weeks. Within the system, large reservoirs were used to mix circulating water drained from the fish tank with city water. Keeping the mixed water uncovered under light allowed slow evaporation of chlorine. The water then was passed through filtration chambers containing charcoal, coarse sand and denitrifying bacteria culture. The filtered water was then used to fill the fish tanks.

In the beginning of the experiment, all the fish were fed vitamin $\mathrm{C}$ free feed for two weeks. The fish were then distributed in eight tanks among which four tanks had normal fish density and were considered as unstressed controlled group. Four other tanks had crowded fish with a density of $50 \mathrm{~g} / \mathrm{l}$ representing stressed group.

A natural photoperiod of 12 light hours and 12 dark hours was maintained throughout the study. Water quality parameters were monitored and optimal water quality was maintained (dissolved oxygen was at a minimum of $6 \mathrm{mg} / 1$ and $\mathrm{pH}$ between 6 and 7.5). Dissolved oxygen and $\mathrm{pH}$ were measured using YSI portable DO and $\mathrm{pH}$ probes.Fish were cared for according to approved animal care protocol and fed twice daily in an amount of $1 \%$ of their average body mass. Excess feed was removed from the tanks using filtration systems attached to the tanks.

\subsection{Feed Preparation}

Diets were formulated using MIXIT-WIN 2+ (Ag Software Consultants, San Diego, CA), based on the essential amino acid (EAA) requirements of Nile tilapia. All diets contained $36 \%$ crude protein $(\mathrm{CP})$ and $8 \%$ lipid (Table 1). Availability of EAA was assumed to be $80 \%$ for all protein-containing ingredients. Ingredients were mixed in a Hobart mixer and pelleted using the chopping end attachment. Diets were air dried to a constant moisture concentration and stored frozen at $-20^{\circ} \mathrm{C}$ prior to feeding. Vitamin $\mathrm{C}$ was added in the phosphorylated form.

\subsection{Sampling}

Sampling was performed after 14 days of feeding with the experimental feed. The fish were starved for 12 hours before sampling. On the sampling day, 3 fish were randomly taken from each tank with the help of a dip net, making the number of samples to be 6 per group. As soon as they were caught, they were put in different marked buckets containing a lethal amount of $200 \mathrm{mg} /$ liter of tricaine methane sulfonate (MS-222) [16] for rapid euthanization. After measuring weight and length, blood was taken from each fish from the caudal vein. The health and stress levels of these fish were then determined by the following measures:condition factor, blood glucose, plasma cortisol, plasma protein, and packed cell volume.

Table 1. Composition of control and experimental diet

\begin{tabular}{|c|c|c|c|c|}
\hline \multirow{2}{*}{ Ingredients } & \multicolumn{2}{|c|}{$\begin{array}{c}\text { Control diet without } \\
\text { vitamin C }\end{array}$} & \multicolumn{2}{c|}{$\begin{array}{c}\text { Experimental diet with } \\
\text { vitamin C }\end{array}$} \\
\cline { 2 - 5 } & Percentage & $\begin{array}{c}\text { Weight } \\
\text { (gm.) }\end{array}$ & Percentage & $\begin{array}{c}\text { Weight } \\
\text { (gm.) }\end{array}$ \\
\hline $\begin{array}{c}\text { Wheat, } \\
\text { whole }\end{array}$ & 24.9 & 996.0 & 24.8 & 992.0 \\
\hline Fish meal & 30.9 & 1236.0 & 30.9 & 1236.0 \\
\hline $\begin{array}{c}\text { Soybean } \\
\text { meal }\end{array}$ & 26.6 & 1064.0 & 26.6 & 1064.0 \\
\hline Canola oil & 4.0 & 165.7 & 4.0 & 165.7 \\
\hline Choline-Cl & 2.0 & 80.0 & 2.0 & 80.0 \\
\hline $\begin{array}{c}\text { Vitamin } \\
\text { premix }\end{array}$ & 0.324 & 13.0 & 0.324 & 13.0 \\
\hline $\begin{array}{c}\text { Mineral } \\
\text { premix }\end{array}$ & 8.0 & 320.0 & 8.0 & 320.0 \\
\hline Lecithin & 1.5 & 60.0 & 1.5 & 60.0 \\
\hline CMC & 2.0 & 80.0 & 2.0 & 80.0 \\
\hline $\begin{array}{c}\text { Vitamin C } \\
\text { PP }\end{array}$ & 0 & 0 & 0.1 & 4 \\
\hline Total & $100.224 \%$ & 4014.7 & $100.224 \%$ & 4014.7 \\
\hline
\end{tabular}

* CMC - Carboxymethylcellulose * PP- Phosphorylated

\subsubsection{Condition Factor}

Length and weight of each individual fish were measured using a meter scale and an electronic balance respectively. Then the weight and length data were used to calculate the condition factor $(\mathrm{K})$ using the following formula [17]:

Condition Factor $(\mathrm{K})=\left[(\right.$ Weight $\left.\times 100) /(\text { Length })^{3}\right]$

\subsubsection{Blood glucose}

A TRUEtrack ${ }^{\circledR}$ glucose meter (Nipro Diagnostics Inc., Osaka, Japan) was calibrated by inserting a test strip into the test slot. A drop of blood from the syringe was added on the designated area of the test strip to measure the glucose [17]. This method has been validated for use in glucose analysis for fish[18].

\subsubsection{Plasma cortisol concentration}

Blood were collected in microfuge tubes containing no anticoagulant and incubated in an upright position at $4^{0} \mathrm{C}$ overnight to allow clotting. Carefully the plasma was aspirated at room temperature for quantitative analysis by cortisol EIA Kit (Enzo Life Sciences Int'l Inc., PA) following a slightly modified protocol of the manufacturer. 
Instead of using $100 \mu$ l of sample as suggested by the manufacturer, $10 \mu 1$ was used and a total volume of $100 \mu \mathrm{l}$ was prepared by diluting with the assay buffer. $1 / 10^{\text {th }}$ sample dilution was necessary because of high concentration of cortisol in the plasma. Spectra Count Microplate Reader (Packard Instrument Company, Meriden, USA) was used to measure optical density at $405 \mathrm{~nm}$. The measured optical density of the standard cortisol solution was used to formulate the following equation:

$\mathrm{y}=-18.99 \ln (\mathrm{x})+185.74$

The value of percent bound, $\mathrm{Y}$ was put into the equation to calculate the value of $\mathrm{x}$, the concentration of cortisol.

\subsubsection{Plasma Protein}

A handheld protein refractometer (VEEGEE Scientific Inc. Kirkland, WA) was used to measure plasma protein content. Using distilled water on to the surface of the prism by adjusting the focus and closing the day-light the machine was calibrated. Two drops of plasma from hematocrit tube were added on to the surface of the prism, the level of total protein was measured through the eyepiece [16].

\subsubsection{Packed Cell Volume}

A single glass capillary tube was filled with blood from the syringe and then one end was capped with Critocaps [16]. The tubes were kept standing for 15 minutes at room temperature. After sampling all the 24 fish, the blood-filled tubes were centrifuged in the micro centrifuge machine for $1000 \mathrm{~g}$ for 5 minutes, resulting separation of the plasma from the blood cells. The hematocrit levels were determined using Micro-Hematocrit Capillary Tube Reader (Monoject Scientific, St. Louis, MO) after the centrifugation [17].

\subsubsection{Statistical Analysis}

The statistical analysis of the data was performed by one way analysis of variance (ANOVA). A post-ANOVA comparison of multiple means was done by Holm-Sidak method. All the experimental groups were compared with each other. The graphical representation was also produced using SigmaPlot 11.0. The error bars within the graphs are depicted as means \pm standard errors of the means (SEM).

\section{Results}

\subsection{Plasma Cortisol Concentration}

After two weeks, all the experimental groups had significantly different concentration of cortisol in blood plasma $(p<0.05)$. The control stressed group showed maximum plasma cortisol concentration. The control unstressed had lower level than that of the control stressed group but yet it was significantly higher than the groups with vitamin $\mathrm{C}$ in their feed $(\mathrm{p}<0.05)$. The unstressed fish receiving vitamin $\mathrm{C}$ complemented feed had the lowest plasma cortisol level of all (Figure 1).

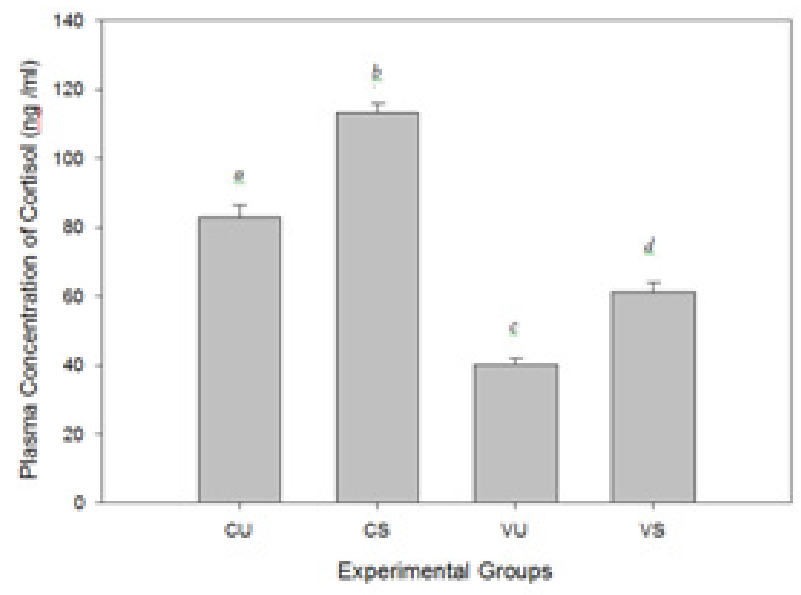

Figure 1. Analysis of cortisol concentration of plasma feeding with vitamin $\mathrm{C}$ free and vitamin $\mathrm{C}$ supplemented feed, reared in two different conditions, controlled and stressed. Data are means \pm SEM. Sample size is 6 fish per group. Experimental fish groups: CU - Control Unstressed, CS Control stressed, VU - vitamin C Unstressed, VS - vitamin C stressed. Different letters indicate significant difference at $\mathrm{p}<0.05$.

\subsection{Blood Glucose Concentration}

Significant variation in concentration of glucose in blood was observed among all three groups $(p<0.05)$, the control stressed group having the highest glucose level. The control unstressed had no significant difference from the vitamin C stressed group. The control group of unstressed fish fed with vitamin $\mathrm{C}$ complemented feed had the lowest blood glucose concentration $(\mathrm{p}<0.05)$ (Figure 2).

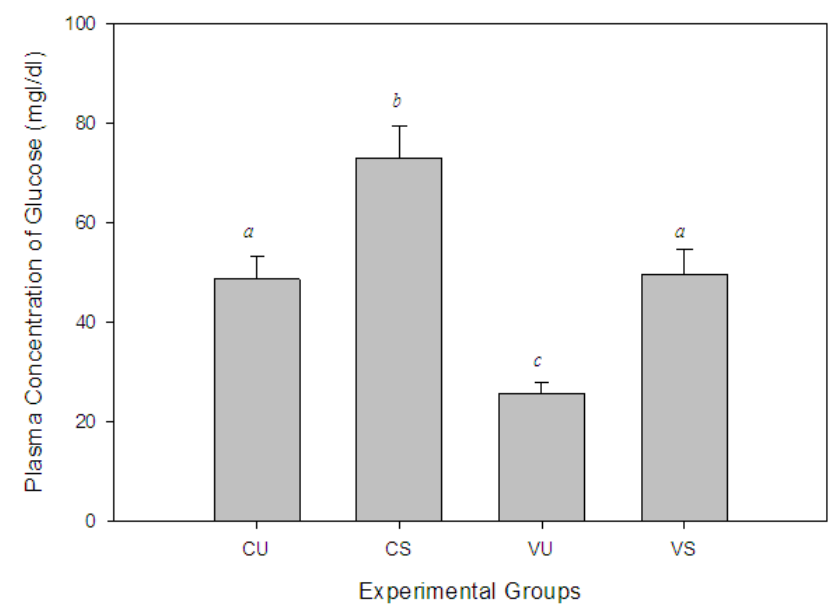

Figure 2. Analysis of concentration of blood glucose feeding with vitamin $\mathrm{C}$ free and vitamin $\mathrm{C}$ supplemented feed, reared in two different conditions, controlled and stressed. Data are means \pm SEM. Sample size is 6 fish per group. Experimental fish groups: CU - Control Unstressed, CS - Control stressed, VU vitamin C Unstressed, VS - vitamin C stressed. Different letters indicate significant difference at $\mathrm{p}<0.05$.

Spearman Rank Order Correlation coefficient between Glucose and cortisol is 0.802 , which delineates significant $(\mathrm{p}<0.05)$ positive correlation among this two parameters - the blood glucose increasing steadily with 
increase in plasma cortisol concentration (Figure 3). An $\mathrm{R}^{2}$ value of 0.637 representing coefficient of determination indicates that the regression line fits the data quite well.

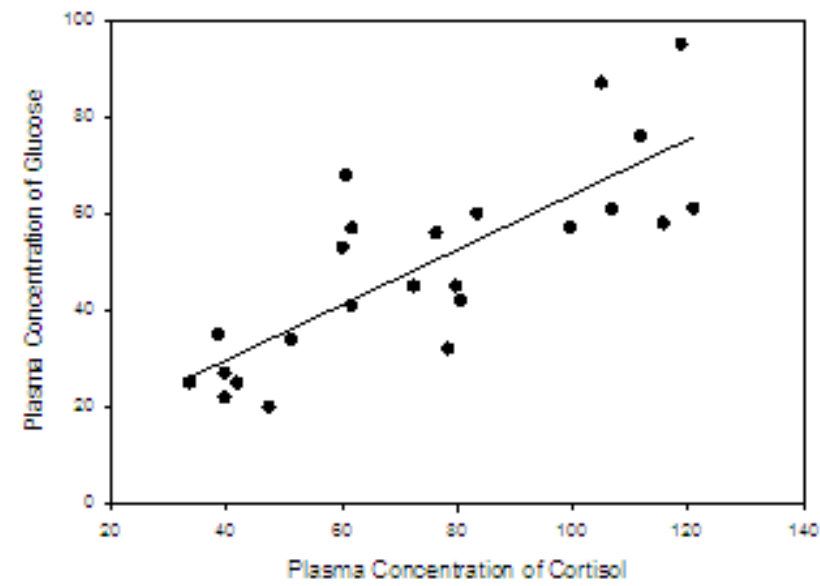

Figure 3. Correlation between plasma cortisol concentrations and blood glucose concentrations.

\subsection{Plasma Protein}

An overall analysis revealed that although not significant, the vitamin $\mathrm{C}$ supplemented groups showed lower plasma protein concentration than the groups without any vitamin $C$. Similarly the total protein amount was lower in the control groups than their stressed group counterparts. When compared individually, the stressed group without receiving any vitamin $\mathrm{C}$ had significantly higher $(\mathrm{p}<0.05)$ protein content in their plasma than the unstressed group receiving vitamin $\mathrm{C}$ supplemented feed (Figure 4).

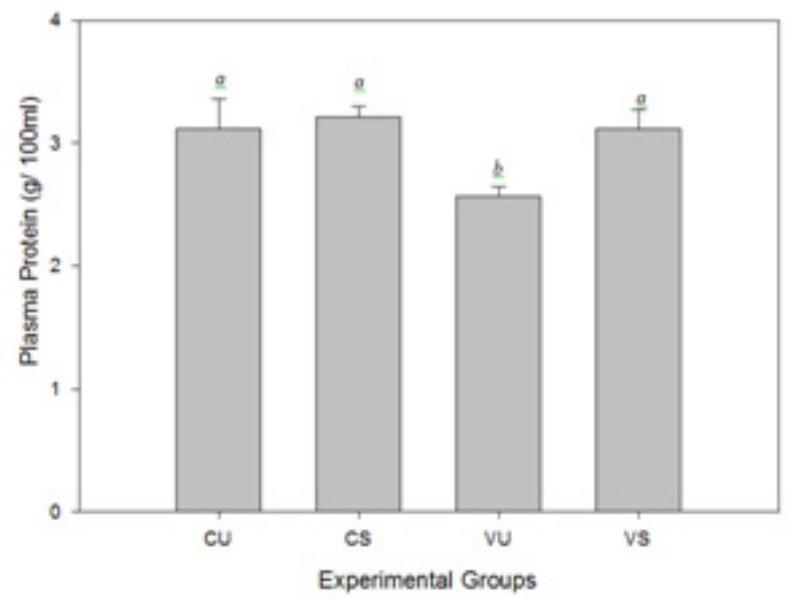

Figure 4. Analysis of concentration of protein in blood plasma feeding with vitamin $C$ free and vitamin $C$ supplemented feed, reared in two different conditions, controlled and stressed. Data are means \pm SEM. Sample size is 6 fish per group. Experimental fish groups: CU - Control Unstressed, CS - Control stressed, VU - vitamin C Unstressed, VS - vitamin $\mathrm{C}$ stressed. Different letters indicate significant difference at $\mathrm{p}<0.05$.

\subsection{Packed Cell Volume}

Among the different treatment groups, there exists a significant difference $(\mathrm{p}<0.05)$ in the percentage of packed cell volume of blood. The two groups - stressed and unstressed without any vitamin $\mathrm{C}$ in their feed had almost equal percentage of blood hematocrit level, which was significantly $(p<0.05)$ lower than the stressed unit with vitamin $\mathrm{C}$ supplementation. Although the unstressed vitamin $\mathrm{C}$ diet group had lower percentage of hematocrit in their blood, it was not statistically significant (Figure 5).

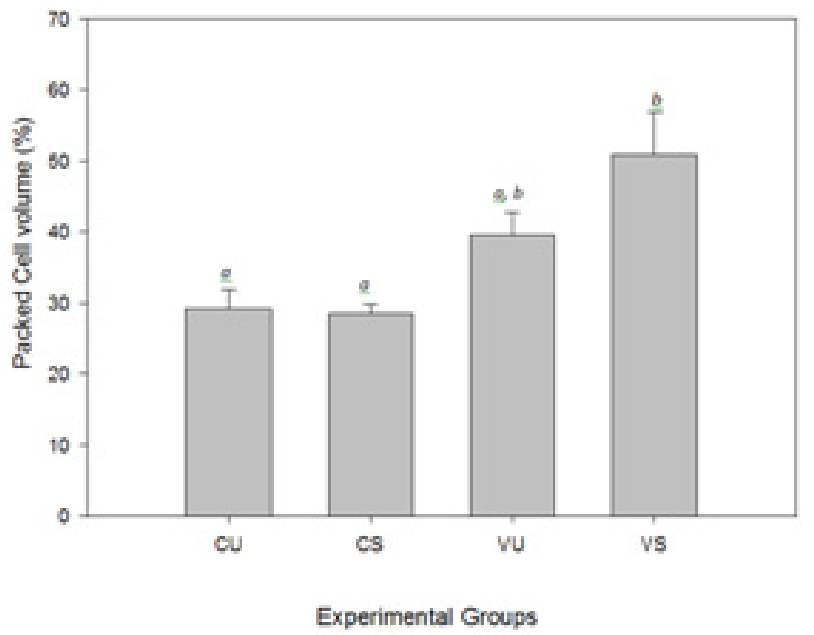

Figure 5. Analysis of the percentage of packed cell volume in blood feeding with vitamin $\mathrm{C}$ free and vitamin C supplemented feed, reared in two different conditions, controlled and stressed. Data are means \pm SEM. Sample size is 6 fish per group. Experimental fish groups: CU - Control Unstressed, CS - Control stressed, VU - vitamin C Unstressed, VS - vitamin $\mathrm{C}$ stressed. Different letters indicate significant difference at $\mathrm{p}<0.05$.

\subsection{Condition Factor}

There was no significant difference in condition factors among fish groups after two weeks of experimentation (Figure 6).

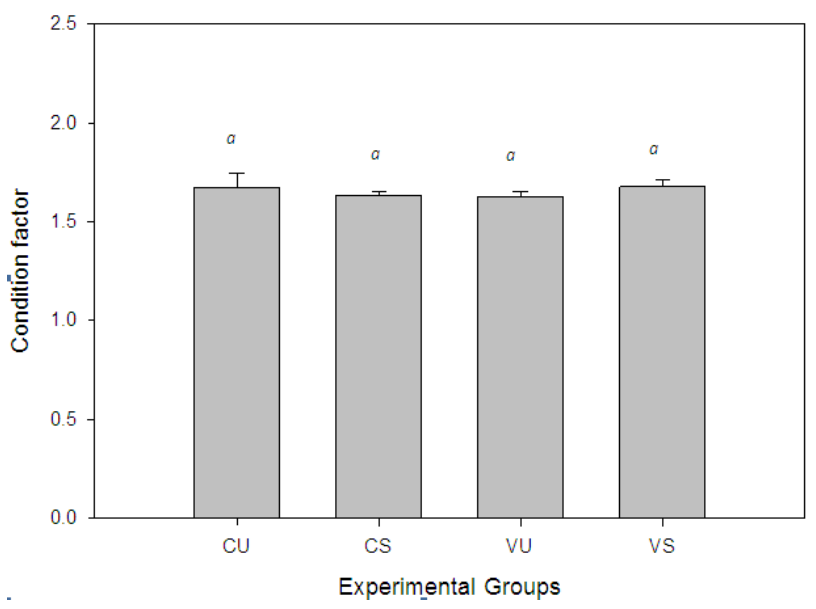

Figure 6. Analysis of condition factor of Tilapia feeding with vitamin C free and vitamin $\mathrm{C}$ supplemented feed, reared in two different conditions, controlled and stressed. Data are means \pm SEM. Sample size is 6 fish per group. Experimental fish groups: CU - Control Unstressed, CS - Control stressed, VU - vitamin C Unstressed, VS - vitamin C stressed. Different 
letters indicate significant difference at $\mathrm{p}<0.05$.

\section{Discussion}

Experiments have been performed to observe the effect of absence of vitamin $\mathrm{C}$ in farmed fish diet. Aanorexia, lethargy, scoliosis, and lordosis were observed in rainbow trout[19, 20]. Soliman et al. [21] observed Nile tilapia fed Vitamin C free diet exhibited erratic and convulsive swimming, anorexia, lethargy, caudal fin erosion, skin haemorrhages and mortality. Objective of the current experiment was to analyze the combined effect of absence of vitamin $\mathrm{C}$ and crowding stress in Tilapia.

The significant difference in both plasma cortisol concentration and blood glucose level between the stressed and the unstressed groups implies that crowding condition exerts stress on fish. This data supports the finding of Rotllant and Tort [22] when they subjected Red porgy (Pagruspagrus) to 3 weeks of chronic stress by crowding. After an initial spike the cortisol levels return to basal values to avoid tissue damage. Therefore, reviewers like Martinez-Porchaset al. [23] has suggested that cortisol might not be very reliable for chronic stress. Some other stressors like Sea lice challenge in Atlantic salmon [24] and organochlorine injection in rainbow trout [25] also produced elevation in plasma cortisol in chronic experiments. Ortuñoet al. [26] showed that plasma cortisol level in Gilthead seabreams shoots up during intense short-term crowding stress of $100 \mathrm{~kg} / \mathrm{m}^{3}$ for 2 hours. Significant higher cortisol concentration of the experimental group after two weeks of rearing in crowded condition supports the validity of plasma cortisol as a good crowding stress biomarker that spikes up in absence of ascorbate.

During their crowding stress experiment on Red porgy (Pagruspagrus), Rotllant and Tort [22] did not observe any significant difference in plasma glucose level. But,Basruret al. [27] observed rise in both plasma cortisol and glucose level during a repeated crowding stress investigation on Atlantic salmon (Salmosalar). Glucose metabolism is affected by cortisol concentration [13, 28], and so a linear relationship is expected between these two chief stress parameters. From our experimental data, a regression analysis reveals a fairly strong correlation $\left(\mathrm{R}^{2}=0.802\right)$ between glucose and cortisol. So, the primary stress response by production of hormones was responded by concurrent rise of blood glucose, a secondary stress response to adapt with the stressed situations.

From the results of plasma cortisol concentration and blood glucose level it can be proposed that vitamin $\mathrm{C}$ helps to reduce the stress response induced by crowding. Vitamin $\mathrm{C}$ has been reported to reduce plasma cortisol level in Tilapia, Oreochromisniloticus exposed to cold stress [29]. We have found that vitamin $C$ supplementation in an amount of 1000 $\mathrm{mg} / \mathrm{kg}$ as suggested by Verlhac and Gabaudan[30], reduces the cortisol concentration in the stressed group even lower than the unstressed group lacking the minimum required amount of dietary vitamin $\mathrm{C}$. The finding that absence of ascorbate is increasing cortisol level somewhat contradicts [31], who concluded that high concentration of ascorbate does not inhibit steroidogenesis. Ortuñoet al. [22] reported that in gilthead seabream, vitamin $\mathrm{C}$ happens to reduce glucose level in stressed groups but not cortisol. The drastic upsurge of both glucose and cortisol in the control group might be due to the fact that our control feed was totally devoid of vitamin $\mathrm{C}$ while in aforementioned researchers maintained a minimum level of ascorbate in their diet.

In terms of total plasma protein, there is no significant difference between the fish, which received vitamin $\mathrm{C}$ from those which did not. Hardieet al.[9] in their experiment on Atlantic salmon and Sealey and Gatlin [32] while experimenting with hybrid striped bass observed no effect of vitamin $\mathrm{C}$ on plasma protein content. On the other hand, pirarucu (Arapaima gigas), in net culture, showed elevation of plasma protein [33]. Similar results were obtained by Pimpimolet al.[34],who worked with Mekong giant catfish (Pangasianodongigas). The contradicting results might arise due to variation of species and experimental settings.

High packed cell volume or blood hematocrit level usually indicates hemoconcentration due to gill damage, dehydration of polycythemia induced by stress [13]. But we did not observe any significant difference of hematocrit level between the stressed and nonstressed groups within each diet group. But we marked a significant rise of packed cell volume in the vitamin $\mathrm{C}$ supplemented stressed group than others. It has been reported by de Menezeset al. [33] that vitamin $\mathrm{C}$ supplementation resulted in increase of Hemoglobin percentage, number of Red blood cells and packed cell volume in pirarucu (Arapaima gigas). Falcon et al. [29] demonstrated that Tilapia submitted to low temperature stress exhibit significantly reduced Hematocrit level when fed with vitamin $\mathrm{C}$ free diet. It has been hypothesized that impairment of iron metabolism and distribution due to deficiency of vitamin $\mathrm{C}$ might decrease $\mathrm{RBC}$ production [35]. As we observed from our experiment, the stressed fish group without vitamin $\mathrm{C}$, despite having significantly higher cortisol and glucose concentration, had significantly lower hematocrit level than their vitamin C fed counterpart. Hence the higher hematocrit level of the group receiving vitamin $\mathrm{C}$ might be an indicator of adaptation.

Solimanetet al. [21] observed that fish feeding with diet devoid of ascorbic acid exhibited significantly $(p<0.01)$ higher condition factor. But in our experiment there were no tangible difference in condition factor among the experimental groups. Had this experiment been carried on over a longer period of time, there might have been some observable difference in condition factor.

The overall result of the experiment clearly illustrates a negative effect of vitamin $\mathrm{C}$ deficiency in commercially cultured Nile tilapia.

\section{Acknowledgements}

We thank Professor Paul Brown of Purdue University, 
West Lafayette, IN for helping us to prepare the ascorbic-acid free fish feed.

\section{REFERENCES}

[1] S. E. W. Bonga. The Stress Response in Fish. Physiological Reviews, 77:591-625, 1997.

[2] I.B. Chatterjee. Vitamin-C synthesis in animals: evolutionary trend. Science and Culture, 210-211, 1973.

[3] V. Verlhac, J.Gabaudan.The Effect of vitamin C on fish health. Saint-Louis Cedex: Centre for Research in Animal Nutrition, Undated.

[4] N. K. Akhilender.Vitamin C in human health and disease is still a mystery? An overview. Nutrition Journal, 2:7 (doi:10.1186/1475-2891-2-7), 2003.

[5] K. Jauncey,A. Soliman, R.Roberts. Ascorbic acid requirements in relation to wound healing in the cultured tilapia Oreochromisniloticus.Aquaculture and Fisheries Management,16:139-149, 1985.

[6] R. Narayanan, Vinodhini.The impact of toxic heavy metals on the hematological parameters in common carp (CyprinuscarpioL.).Iranian Journal of Environmental Health Science \& Engineering, 6:23-28, 2009.

[7] M. Abdel-Tawwab, A. M. E. Shalaby,M. H. Ahmad, A. E. K. Yassir. Effect of supplemental Dietary L-ascorbic acid (Vtiamin C) on mercury detoxification, physiological aspects and grwoth performance of Nile Tilapia.New Dimensions on Farmed Tilapia. Manila: 6th International Symposium on Tilapia in Aquaculture. 159-171, 2004.

[8] J. E. Halver. The role of ascorbic acid in fish diseaseand tissue repair.Bulletin of the Japanese Society of Scientific Fisheries, 38:79-92, 1972

[9] L. J. Hardie, T. C. Fletcher, C. J. Secombes. The effect of dietary vitamin $\mathrm{C}$ on the immune response of the Atlantic salmon (Salmosalar L.).Aquaculture, 95:201-214, 1991.

[10] S. C. Shiau, C.Hsu. Vitamin E sparing effect by dietary vitamin $\mathrm{C}$ in juvenile Hybrid tilapia, Oreochromisniloticus $\mathrm{x}$ O. aureus. Aquaculture, 210:335-342, 2000.

[11] G. Wedemeyer. Stress induced ascorbic acid depletion and cortisol production in two salmonid fishes.Comparative Biochemistry and Physiology,1247-1251, 1969.

[12] A. D. Pickering. The concept of biological stress. The concept of biological stress. In stress and fish, A. D. Pickering (ed.).Academic Press, London, England pp.63-92, 1981.

[13] G. A. Wedemeyer, B. Barton, D. Mcleay, C. Schreck, P.B. Moyle. Stress and acclimation. Pages 451-477 in C.B. Schreck and P. B. Moyle, editors. Methods forfish biology. American Fisheries Society, Bethesda, Maryland, 1990.

[14] M. Jaffa, M. Vitamin C can curb those stress associated losses.Fish Farming International,12:18-19, 1989.

[15] A. E. Kitabchi. Ascorbic acid in steroidogenesis.Nature,215:1385-1386, 1967.
[16] M. Gensic, P. J. Wissing,T. R. Keefe,A. Mustafa. Effects of iodized feed on stress modulation in steelhead trout,Oncorhynchusmykiss (Walbaum).Aquaculture Research,35:1117-1121, 2004.

[17] A. Mustafa,C. MacWilliams,N. Fernandez, K.Matchett, G. A.Conboy, Burka.Effects of sea lice (LepeophtheirussalmonisKröyer, 1837) infestation on macrophage functions in Atlantic salmon (Salmosalar L.).Fish and Shellfish Immunology, 10:47-59, 2000.

[18] G. K. Iwama, J. D. Morgan,B. A. Barton, B.A.Simple field methods for monitoring stress and general condition of fish. Aquaculture Research,26: 273-282, 1995.

[19] J. W. Hilton, C. Y. Cho, S. J. Slinger. Effect of Graded Levels of Supplemental Ascorbic Acid in Practical Diets Fed to Rainbow Trout (Salmogairdneri).Journal of the Fisheries Research Board of Canada,35(4): 431-436, 1978.

[20] M. N. Alexis, K. K. Karanikolasa, R. H. Richards. Pathological findings owing to the lack of ascorbic acid in cultured gilthead bream (Sparusaurata L.). Aquaculture, 151: 209-218, 1997.

[21] A. K. Soliman, K. Jauncey, R. J. Roberts. Water-soluble vitamin requirements of tilapia: ascorbic acid (vitamin $\mathrm{C}$ ) requirement of Nile tilapia, Oreochromisniloticus (L.).Aquaculture Research,25:269-278, 1994.

[22] J. Rotllant, L.Tort. Cortisol and glucose responses after acute stress by net handling in the sparid red porgy previously subjected to crowding stress.Journal of Fish Biology,51:21-28, 1997.

[23] M. Martinez-Porchas, L. R. Martinez-Cordova, R.Ramos-Enriquez. Cortisol and Glucose: Reliable indicators of fish stress?Pan-American Journal of Aquatic Sciences,4:158-178, 2009.

[24] J. M. Bowers, A. Mustafa, D. J. Speare,G. A. Conboy,M. Brimacombe, D. E.Sims,J. F. Burka. The physiological response of Atlantic salmon, Salmosalar L., to a single experimental challenge with sea lice Lepeophtheirussalmonis.Journal of Fish Diseases, 23:165-172, 2000.

[25] S. Benguira, V. S. Leblond, J. P. Weber, A. Hontela. Loss of capacity to elevate plasma cortisol in rainbow trout (Oncorhynchusmykiss) treated with a single injection of o,p'-dichlorodiphenyldichloroethane. Environ Toxicology Chemistry, 21:1753-1756, 2002.

[26] J. Ortuño, M.A. Esteban, J. Meseguer. Effects of short-term crowding stress on the gilthead seabream (Sparusaurata L) innate immune response. Fish and Shellfish Immunology, 11:187-197, 2001.

[27] T. V. Basrur, R. Longland, R. J. Wilkinson. Effects of repeated crowding on the stress response and growth performance in Atlantic salmon (Salmosalar). Fish Physiology Biochemistry, 36:445-50, 2010.

[28] B. A. Barton, G. K. Iwama. Physiological changes in fish from stress in aquaculture with emphasis on the response and effects of corticosteroids. Annual Review of Fish Diseases, $1: 3-26,1991$.

[29] D. Falcon, M. M. Barros, L. E. Pezzato, F. G. Sampaio,H. Hisano. Physiological Responses of Nile Tilapia, Oreochromisniloticus Fed vitamin C- and 
Lipid-Supplemented Diets and Submitted to Low-Temperature Stress.Journal of the World Aquaculture Society,38:287-295, 2007.

[30] V. Verlhac, A. N'Doye, J.Gabaudan, D.Troutaud, P. Deschaux. Vitamin nutrition and fish immunity: influence of antioxidant vitamins (C and $\mathrm{E}$ ) on immune response of rainbow trout. Fish Nutrition in Practice Les Colloques (INRA eds,) 61: 167-177, 1993.

[31] H. Dabrowska, K. Dabrowski, K. Meyer-Burgdorff, W. Hanke,K. D. Gunther.The effect of large doses of vitamin C and magnesium on stress responses in common carp, Cyprinuscarpio. Comparative Biochemistry and Physiology Part A: Physiology, 99:681-685, 1991.

[32] W. M. Sealey, D.M. Gatlin 3rd. Dietary vitamin C and vitamin $\mathrm{E}$ interact to influence growth and tissue composition of juvenile hybrid striped bass (Moronechrysops (female) x M. saxatilis (male)) but have limited effects on immune responses.Journal of
Nutrition, 132:748-755, 2002.

[33] G. C. de Menezes, M. Tavares-Dias, E. A. Ono,J. I. A. de Andrade,E. M. Brasil, R. Roubach, E. C.Urbinati, J. L. Marcon,E. G. Affonso, E.G. The influence of dietary vitaminC and $\mathrm{E}$ supplementation on the physiological response of pirarucu, Arapaima gigas, in net culture.Comparative Biochemistry and Physiology - Part A: Molecular \& Integrative Physiology,145:274-279, 2006.

[34] T. Pimpimol, K.Phoonsamran, C.Chitmanat. Effect of dietary vitamin $\mathrm{C}$ supplementation on the blood parameters of Mekong giant catfish (Pangasianodongigas). International Journal of Agriculture and Biology,14:256-260, 2012.

[35] S. Albrektsen, O. Lie, K. Sanders. Ascorbylpalmitate as a dietary vitamin C source for rainbow trout (Salmogairdneri).Aquaculture, 71:359-365, 1988 